\title{
Containing Populism at the Cost of Democracy? Political vs. Economic Responses to Democratic Backsliding in the EU
}

\begin{abstract}
This paper critically engages the legal and political framework for responding to democracy and rule of law backsliding in the EU. I develop a new and original critique of Article 7 TEU based on it being democratically illegitimate and normatively incoherent qua itself in conflict with EU fundamental values. Other more incremental and scaleable responses are desirable, and the paper moves on to assess the legitimacy of economic sanctions such as tying access to EU funds to performance on democratic and rule of law indicators or imposing fines on backsliding states. I hold such sanctions to be a priori legitimate, and argue that in some cases economic sanctions are even normatively required, given that $\mathrm{EU}$ material support of backsliding member states can amount to material complicity in their backsliding. However, an economic conditionality mechanism would need to be designed to minimize unjust and counterproductive effects. One way to pursue this could be to complement sanctions against the backsliding government with investment for prodemocratic actors in that state.
\end{abstract}

Keywords: Article 7; democratic backsliding; democratic legitimacy; European Union; democratic equality; economic sanctions.

\section{Introduction}

It can no longer be taken for granted that EU member states are on a forward trajectory in terms of democracy and the rule of law (Kelemen, 2017; Kochenov, 2015; Kochenov and Pech, 2016; Pech and Scheppele 2017, Oliver and Stefanelli, 2016). In the 2019 edition of the Freedom in the World Index, Hungary dropped below the threshold democratic indicators required to be categorized a 'Free' country - the first EU member state ever to do so. Other member states particularly Poland under the leadership of the Law and Justice Party (PiS), are also backsliding on democracy and the rule of law. Yet Article 2 of the Treaty on European Union (TEU), the core legal document of European integration, clearly states that:

The Union is founded on the values of respect for human dignity, freedom, democracy, equality, the rule of law and respect for human rights, including the rights of persons belonging to minorities. These values are common to the Member States in a society in which pluralism, non-discrimination, tolerance, justice, solidarity and equality between women and men prevail (TEU, 2012: Article 2). 
The formulation of Article 2 - which holds that the values listed 'are' shared and that normative commitments 'prevail' - is at odds with current trends towards democratic and rule of law backsliding in member states. This raises the question of what the EU should do to guarantee the democratic character of EU member states and EU institutions when member states are at risk of backsliding on fundamental values.

The TEU has a mechanism to deal with such an eventuality - Article 7 TEU. It states that:

1. On a reasoned proposal by one third of the Member States, by the European Parliament or by the European Commission, the Council, acting by a majority of four fifths of its members after obtaining the consent of the European Parliament, may determine that there is a clear risk of a serious breach by a Member State of the values referred to in Article 2 [...]

2. The European Council, acting by unanimity on a proposal by one third of the Member States or by the Commission and after obtaining the consent of the European Parliament, may determine the existence of a serious and persistent breach by a Member State of the values referred to in Article 2, after inviting the Member State in question to submit its observations.

3. Where a determination under paragraph 2 has been made, the Council, acting by a qualified majority, may decide to suspend certain of the rights deriving from the application of the Treaties to the Member State in question, including the voting rights of the representative of the government of that Member State in the Council. In doing so, the Council shall take into account the possible consequences of such a suspension on the rights and obligations of natural and legal persons. The obligations of the Member State in question under this Treaty shall in any case continue to be binding on that State.

4. The Council, acting by a qualified majority, may decide subsequently to vary or revoke measures taken under paragraph 3 in response to changes in the situation which led to their being imposed [...] (TEU, 2012: Article 7, emphasis added).

Article 7 proceedings have been started against both Poland and Hungary for breaches of Article 2 values. Polish and Hungarian politicians have argued that, far from backsliding on democracy, they are implementing the sovereign will of their people and have a democratic mandate to do so. Further, because Article 7.2 requires the unanimity of the European Council at ascertaining a serious and persistent breach of Article 2 values, a simple alliance of Poland 
and Hungary are sufficient to block any sanctions from being imposed; the unanimity requirement is thus a barrier to the practical efficacy of the Article 7 procedure. Another element which is said to block the working of Article 7 is the fact that the type of sanction it proposes is a slow, blunt instrument, often (although not without critique) described as the 'nuclear option.' As such, it is unlikely ever to be used (Oliver and Stefanelli, 2016; Pech et al., 2016: 37; compare with Kochenov, 2017).

As well as criticizing the inefficacy of the Article 7 procedure, commentators have proposed a range of new responses to democratic and rule of law backsliding in the EU. Some of these look at developing quicker, more majoritarian sanctions, and on complementing political with economic sanctions (e.g. Pech and Scheppele, 2017; Kochenov, 2015; Kochenov and Pech, 2016). The justification for this move is usually framed as an issue of necessity: given the (assumed) salience of the Article 2 values, and continued democratic and rule of law backsliding by EU member states despite the Article 7 procedure, new procedures and tools are needed. Proposals for new procedures are evaluated on their perceived ability to reverse democratic and rule of law backsliding, or at least to effectively contain it.

The European Commission already recognized the difficulties with the Article 7 procedure in 2013 and proposed an additional mechanism, adopted in 2014, known as the 'Rule of Law Framework'; however, this framework merely adds additional steps of evaluation and dialogue before a recommendation that recourse is needed to the Article 7 procedure. Given the failings of this dialogue (i.e. in light of increasing backsliding in Hungary and Poland since 2014), and the fact that this extended procedure exacerbates a problem already inherent in the Article 7 procedure - that it is slow - it is hard to see how the Rule of Law Framework has met criticisms made of Article 7.

This paper contributes to the literature of criticizing the current legal and political framework of responding to democracy and rule of law backsliding in the European Union. However, rather than focusing on the empirical questions of the inefficacy of the Article 7 procedure and the putative efficacy of alternatives, this article assesses Article 7, and certain alternative mechanisms, from a largely normative perspective. Specifically, I argue that Article 7 is in conflict with the principle of democratic equality in that it violates a minimum democratic standard whereby all who are legally subject to a law ought to have a formally equal stake in its authorization. Other more incremental and scaleable economic responses are therefore desirable, and the remainder of this paper assesses the legitimacy and normative desirability of such responses.

The structure of the paper is as follows: Part 1 makes the case that Article 7 is in conflict with the principle of democratic equality (which follows from the 
Article 2 values of democracy and equality) in that it violates the All Subjected Principle. Next, in part 2, I assess the legitimacy of economic sanctions such as tying access to EU funds to performance on democratic and rule of law indicators. I hold such sanctions to be $a$ priori legitimate, and appropriate, given the largely economic nature of the European integration project. Further, I argue that in some cases economic sanctions are even normatively required given that EU material support of backsliding member states can amount to material complicity in their backsliding.

While economic sanctions are a priori legitimate and do not undermine the EU fundamental values of equality and democracy, there are risks that they are otherwise unjust, in that they could impose penalties on innocent bystanders, or counter-productive, given that they may negatively impact economic growth in member states, which has been shown empirically to contribute to state's democratic stability. In part 3, I consider such objections and I argue that, indeed, the risk of 'injustice externalities' and counterproductive effects is serious. To address these concerns, I argue that the 'negative' arm of any economic conditionality or sanctions mechanism ought to be accompanied by a 'positive' arm of investment in a backsliding state's prodemocratic actors such that injustices and counterproductive effects of sanctions are minimized. Such investments would have the added advantage of materially and symbolically boosting prodemocratic actors in backsliding member states, which, regardless of the empirical efficacy of civil society support, would contribute to the goal of the EU proactively committing to the fundamental values listed in Article 2.

\section{A Different Line of Critique: Article $\mathbf{7}$ at Mixed Purposes}

Critically engaging, as others have done, the procedural requirements, slow speed, severity, and type of sanction currently formalized in Article 7 is important, but it misses another line of critical reflection that looks at the normative coherence of the rule of law procedure. Such a reflection asks whether the sanctions mechanism that Article 7 lays out for member states in breach of EU fundamental values is itself in line with those values. The hypothesis explored here is that it is not: stripping a member state of their vote in the Council would be a violation of the fundamental values of democracy and equality, and especially of the procedural expression of the intersection of these values - democratic equality. Thus, the main reason that Article 7 is in conflict with democratic legitimacy is that it breaks with a minimal standard of democratic processes whereby all those legally subject to a rule or policy ought to have a formally equal stake in authorizing it. Article 7 allows for the eventuality of a member state losing its right to vote in the Council - a key legislative body of the European Union - while continuing to be bound to the rules and policies (co)determined by Council votes. 
The importance of this argument for Article 7 being at 'mixed purposes' normatively is grounded on the value of normative coherence. Following the distinction by Joseph Raz, by normative coherence I mean 'weak' coherence whereby a given set of rules, policies and principles do not fall into contradiction with one another, rather than 'strong' coherence where they all follow from a unitary foundational principle (Raz, 1992). To say that Article 7 is normatively incoherent in light of the values of democracy and equality, then, is to say that it falls into contradiction with those values. This normative incoherence is not mere moral 'hypocrisy' but has an important practical dimension. If the sanctions-mechanism detailed in Article 7 cannot be used without undermining the grounds for its existence - the values of democracy and equality - then the procedure laid out in Article 7 can never be successful. Even if the procedure succeeds in reversing democracy and rule of law backsliding in a given member state, it does so at the cost of democratic equality. ${ }^{1}$

The purpose of Article 7 is to try to prevent and, if necessary, sanction breaches of the fundamental values of the EU listed in Article 2:

The Union is founded on the values of respect for human dignity, freedom, democracy, equality, the rule of law and respect for human rights, including the rights of persons belonging to minorities. These values are common to the Member States in a society in which pluralism, non-discrimination, tolerance, justice, solidarity and equality between women and men prevail (TEU, 2012: Article 2).

The sanction laid out in Article 7.3 is in conflict with the EU fundamental values of democracy and equality. Article 7.3 stipulates the possible sanction of a member state of the EU determined to be in 'serious and persistent breach' of one of the values referred to in Article 2, namely, the suspension of 'certain of the rights deriving from the application of the Treaties to the Member State in question, including the voting rights of the representative of the government of that Member State in the Council' (TEU, 2012: Article 7.3). Article 2 values include 'the values of respect for human dignity, freedom, democracy, equality, the rule of law and respect for human rights' (TEU, 2012: Article 2).

What would it mean to respect the values of democracy and equality? At the level of individual citizens of a democratic state, a minimal democratic standard holds that all those legally and permanently subject to a legally-binding rule or policy (in short, a law) ought to have an equal stake in co-authorizing that law. In democratic theory this standard is known as the 'all those subjected' standard or

1 I have made a structurally similar critique of EU democracy promotion, arguing that certain anti-democratic measures in EU-negotiated free trade agreements undermine the democratic character of EU foreign policy even if they would have the eventual effect of democratizing the partner state (Theuns, 2019; see also Theuns, 2017). 
'All Subjected Principle.' What such a standard does is give a principled reason for the inclusion or exclusion of any given person into the body of democratic citizens with equal civil and political rights - the demos. Being 'permanently subjected to the binding laws' of a polity interferes with a subject's autonomy and must therefore be justified to them (Scherz, 2013: 4). The democratic process offers a way of justifying such interference or 'subjection' in a neutral manner by granting all permanent residents of a given territory the right to participate in a formally-equal fashion in democratic processes (Song, 2012), typically an equal vote to elect the legislative body. ${ }^{2}$

It is important to note that the standard whereby 'all subjected' ought to have an equal stake in democratic decision-making processes is not the only standard in the literature in democratic theory over the legitimate boundaries of the demos. Some argue that democratic equality requires that all those 'affected' by a decision ought to have an equal stake in it (Goodin, 2007) or that all those 'coerced' by a law ought to be able to co-authorise that law (LópezGuerra, 2005). This article is not the place to weigh in on this complex debate. It suffices to notice that the All Subjected Principle, when limited territorially, constitutes the minimal criterion for inclusion in the demos amongst these views; the other dominant criteria that have been proposed would all include many more persons in the demos, especially those criteria that seek to extend the demos beyond a territorial polity (Goodin, 2007; Abizadeh, 2008; cf. Song, 2012). Thus, for the sake of this article, I assume the validity of the All Subjected Principle. If a more expansive principle of inclusion is correct, my critique of the normative incoherence of Article 7 is all the stronger. ${ }^{3}$

The case for the normative incoherence of Article 7 in light of the Article 2 fundamental values of democracy and equality is straightforward with the All Subjected Principle in mind. Were the sanction in Article 7.3 to be activated against a member state such that the state in question loses its right to vote in the Council, that state could not legitimately be subjected to the (otherwise legally authoritative) decisions of the Council. Yet, Article 7 states explicitly that, for such a disenfranchised state, 'The obligations [...] under this Treaty shall in any case continue to be binding' (TEU, 2012: Article 7.3).

One complicating factor, however, is that the All Subjected Principle (and the alternative normative principles for inclusion in the demos) were designed for

2 Note that it is enough, under such a standard, to be legally bound 'in principle' by a law, even if one is not otherwise directly affected by it.

3 While accepting a stronger version of the All Subjected Principle would render my argument for the normative incoherence of Article 7 stronger still, expansive versions may be incompatible with the arguments for an expulsions mechanism I outline in section 3. For instance, Arash Abizadeh's views on the 'unbounded demos' (Abizadeh, 2008) require all persons coerced by a democratic decision to have a formal stake in them, rendering moot territoriality or stable membership as fundamental characteristics of a democratic polity. This issue cannot be explored further here, but see Song (2012) for an illuminating discussion. 
citizens, and the context of Article 7 concerns the votes of the representatives of governments. While democratic legitimacy principles posit strong normative reasons to treat all citizens as free and equal, the same cannot be assumed to be true for governments (Gaedeke, 2016). Ordinarily, there is little trouble in applying such a principle of democratic equality to argue that states subject to the laws of the EU ought to have voting rights in EU institutional decisionmaking bodies such as the Council (and, proportionally to their population, in the European Parliament). Indeed, I have used this logic to argue that the EU foreign policy instruments such as the European Neighbourhood Policy are democratically illegitimate when they require states that are not EU members to adopt large swathes of the acqui communautaire in order to access privileges (Theuns, 2017). However, the particularities of democratic and rule of law backsliding throw up an additional hurdle: it is only when we assume that a given government is the democratically legitimate representative of its citizens that their authority to (co)decide in institutions like the Council is justified. But if a state has seriously backslidden on democracy and the rule of law, is it still a legitimate representative of its citizens in this multilevel democratic structure?

The answer must be no - there will be a point of democratic and rule of law backsliding when an EU member state's government can no longer be considered the legitimate representative of its citizens. ${ }^{4}$ But that does not help the legitimacy and normative coherence of Article 7. States that are sufficiently democratic ought, under the All Subjected Principle, to have an equal stake in democratic rule-making and rule-authorization (in this context, an equal vote in the Council) while states that are insufficiently democratic cannot legitimately be bound to the Council's decisions - at least not via an argument on the decisions of the Council being authoritative in light of the Council's democratic legitimacy. ${ }^{5}$ In other words, if a backsliding member state is still 'democratic enough,' its right to an equal vote in the Council must be guaranteed, whereas if it is not, it must lose its vote, but cannot be bound to Council decision-making. ${ }^{6}$

We can therefore conclude that Article 7 is currently both normatively incoherent and democratically illegitimate. However, the EU doing nothing about democratic backsliding in its member states is also problematic from a democratic point of view. If a member state backslides on democracy and

4 Ascertaining where this threshold lies in practice is doubly difficult; first, different fuller specifications of the normative standard of democratic legitimacy will result in differing standards of adequacy. Second, even where a standard has been settled, due to the fact that such a standard will consist of a myriad of different constitutional, legal and political elements with complex interactions it is exceedingly difficult to measure the aggregate legitimacy of a particular state using 'checklists' (Scheppele, 2013).

5 Nor can such states participate procedurally in Council decision-making procedures if one wishes to protect the democratic legitimacy of such procedures. I return to this point in part 2.

6 The question of the proper boundary between the standards 'sufficiently' and 'insufficiently democratic' will not be addressed here, nor the question of the appropriate decision-procedure to determine when member states fall on the wrong side of such a boundary. These are important questions if the argument in this paper is convincing, but since they are secondary to the core argument, their consideration is postponed. 
the rule of law, even if it remains 'sufficiently' democratic to be considered a legitimate representative of its citizens for the time being, it may still taint the democratic quality of EU decision-making. Doing nothing were an EU member state to become frankly autocratic would, of course, be even worse. The next section therefore explores the legitimacy of alternative mechanisms by which the EU could respond to democratic backsliding in member states.

\section{The Legitimacy of Economic Sanctions and the Complicity of Doing Nothing}

The normative incoherence of the current Article 7 procedure in light of the fundamental values listed in Article 2, notwithstanding the well-documented inefficacy of the procedure in reining in democratic backsliding in certain EU member states, leaves the EU with a dilemma. How is it to ensure it remains a polity that can affirm its commitment to, inter alia, democracy, equality and the rule of law? Jan-Werner Müller has noted (2015: 145-146) that there are only two ways out of this dilemma. Either 1) the EU must become more proactive in regulating, through negative and positive conditionality mechanisms, member state's commitment to fundamental values or, 2) the EU must formalize a procedure by which member states that fall in serious and persistent breach of Article 2 values can be expelled from the Union. The second is, undoubtedly, an extreme course of action, although it may be necessary to guarantee the EU's democratic character in extremis. This section looks instead at the legitimacy and desirability of economic sanctions.

\section{Positive and negative conditionality for backsliding}

Tying economic conditionality mechanisms - whether in the sense of positive incentives (more funding) or negative sanctions (e.g. fines, or the withdrawal of allocated EU structural funds) - to member state's performance on democracy and rule of law indicators seems to be a no-brainer. The EU's primary power and an unquestionable aggregate benefit to its member states is the single market. Indeed, the bulk of EU law is geared towards guaranteeing the four market freedoms (freedom of movement of goods, capital, people and services). It seems appropriate that those member states not playing by the rules could see themselves locked out of part of their share in the benefits of EU legal, political and economic integration. Indeed, economic conditionality mechanisms to safeguard rule of law and democracy standards have been proposed by a wide range of academic, political, and civil society actors (e.g. Argyropoulou, 2019; Bachmaier, 2019; Scheppele, 2016; and Šelih et al., 2017), and the Commission has also presented a Regulation proposal tying EU budgetary disbursement to the rule of law (European Commission, Secretariat-General, 2018). ${ }^{7}$

7 Adopted under Art. 322(1) (a) TFEU and Art. 106 a Treaty Euratom. 
Beyond the general appropriateness of an economic response to democracy and rule of law backsliding being part of the repertoire of tools at the EU's disposal, there is another distinct reason why an economic response may be the right initial reaction to the cases of backsliding that the EU is currently facing. The two countries most frequently the subject of concern regarding democratic backsliding, Hungary and Poland, have been massive net economic beneficiaries of the EU project. ${ }^{8}$ Beyond the 'diffuse' positive aggregate impact of EU market integration through allowing unfettered investment and trade, there is also the more direct positive impact of EU structural, investment and cohesion funds into Hungary and Poland, which has been a very substantial element of their economic growth in the last decade. ${ }^{9}$

Regardless of the particularities of the Hungarian and Polish cases (and, to be sure, they are not the only states in the EU struggling with democracy and the rule of law), the economic domain is the one where the EU has the most experience, and one that would dovetail with other tools the EU uses to ensure compliance with its legislation. Economic conditionality mechanisms also have the advantage of being very fine-grained - initial and justified concerns over a member state backsliding on Article 2 values could be met with minor and temporary freezes to that country's full access to structural and investment funds, with funds to be released when the concerns are addressed. Graver instances of backsliding can be met by more severe and longer-lasting economic sanctions, including, eventually, large-scale fines and limitations on the access of those state's economies to the EU single market.

It is hoped that scaleable measures such as these, aimed at withdrawing EU economic support for member states continuing down paths of autocratization, may have the effect either of watering down support for the backsliding regime or democracy and rule of law reform by those states. However, the normative urgency of taking such actions in the face of backsliding is not contingent on their instrumental success at bringing about an end to state's backsliding trajectories.

\section{EU inaction as complicity in autocratization}

The fact that EU member states benefit, in the aggregate, from economic integration has an important implication on the normative urgency of an economic conditionality mechanism. Where a member state is in serious and persistent breach of EU fundamental values such as democracy and the rule of

8 By this I mean 'net' beneficiaries, we must not forget that there are also many Hungarians and Poles who have personally lost out as a result of their country's integration into the EU and the single market.

9 We must be careful here. While it is true that Hungary and Poland are both backsliding states and net beneficiaries of EU structural funds, it may not always be the case that backsliding states are also net beneficiaries. As such, it is important to design and justify policy responses to democracy and rule of law backsliding that are equipped and appropriate to respond to potential backsliding in any member state (see Šelih et al., 2017: 11-12). 
law, and continue to receive large-scale economic benefits from the EU in terms of trade advantages and structural funds, the EU can be said to be complicit in that state's backsliding.

By complicity I mean that normative wrong whereby an agent variously enables, induces, encourages, permits or fails to prevent another wrong, where that failure is blameworthy. In the case of the above argument, the complicity in question rests in part on EU inaction in the face of democratic and rule of law backsliding, but also on the EU enabling populist autocratizing projects by subsidizing, on a large scale, the economies of countries undergoing processes of de-democratization - Daniel Kelemen calls this the second pillar of 'Europe's authoritarian equilibrium' (the first is party political support of backsliders in European political groups and freedom of movement generating remittances and depleting opposition: Kelemen, 2020).

Importantly, complicity in this sense is distinct from (collective or shared) responsibility for wrongdoing and from co-authorship. Collective or shared responsibility and, a fortiori, co-authorship rest on collective agency. The act in question must be enacted by all those sharing in collective responsibility or co-authorizing the act. In contrast, to be complicit in a wrongful act one need not be an agent of that action (Lepora and Goodin, 2013), one need merely to make a potentially crucial contribution to it by one's action or blameworthy omission. ${ }^{10}$

One standard way to become complicit is by blameworthy omission. Here, an agent is complicit because they ought to have acted to prevent a harmful act, but failed to do so. One further important point is that a complicitous agent need not share the wrongful aims of the agent in whose wrongful acts they are complicitous (Lepora and Goodin, 2016). That, of course, would be worse, but it is enough to be complicit that one could or reasonably should have foreseen that one's act or wrongful omission could contribute to another agent's wrongful action. This understanding of complicity by omission, where that omission does not share in the wrongful aims of the primary agent, is key to my charge against the EU.

Sometimes complicity in an act will contribute directly to the success of the project of autocratization - as has been argued is the case for Orban whose enduring popularity amongst some Hungarians is in part due to economic growth in Hungary, which in turn is in no small part tied to EU market integration and structural funds (Kelemen, 2020). But this need not be the case for the argument of complicity to have bite. Even simply the macro-economic support

10 Lepora and Goodin's analysis of complicity is an excellent starting point for more detailed deliberation of the concept (2013; 2016). My usage does not track theirs fully, however, as they label as connivance 'turning a blind eye' to others' wrongdoing (2013: 44-47), while I subsume 'wrongfully failing to act' under complicity by omission. Nothing in my argument hinges on this conceptual distinction. 
of a backsliding government through the operation of the single market, and $a$ fortiori direct investment in that government's activities (as with structural and cohesion funds), sends the message that the government in question is a worthy economic and political partner. This is all the more so given the deep political integration that is inseparable from EU membership (in contrast, for instance, with an international free trade agreement). Doing nothing, or doing too little, sends the message that democracy and rule of law backsliding in the EU is a minor or peripheral problem, and that the EU's commitment to the Article 2 fundamental values is skin-deep.

The above point about complicity has purchase regardless of whether such an economic sanctions regime would or would not in fact bring member states back into the democratic fold. It is enough to recognize that democracy and rule of law backsliding are lamentable developments that bring states into conflict with EU fundamental values declared in Article 2 to see the need for withdrawing economic support for states with governments pursuing an autocratization agenda. The fact that withdrawing such support may have the upshot of contributing to reversing the trend of backsliding, while positive, is largely coincidental to the normative point about complicity.

One question that remains, however, is whether economic conditionality mechanisms tied to democratic and rule of law backsliding would themselves be normatively coherent with the values the EU professes to hold in Article 2. The value of equality in particular may give us pause. Clearly, selecting certain member states for economic sanctions, or making their enjoyment of certain structural funds conditional on their reforming certain practices that put them at risk of serious breach of EU fundamental values, is treating them unequally to other member states not subject to such limitations. Is this an affront to their equality? No. Or at least, not necessarily.

The relevant equality here is not that member states are treated equally, in the sense of being treated in the same way. Rather, it is important that all member states are equally subjected to the same framework of rules that leads to conditionality mechanisms being imposed in specified cases of democratic and rule of law backsliding. To see this, it is helpful to think of a citizen's equality before the law, which works in much the same way. There is no affront to equality when an individual, as a consequence of law-breaking behaviour, is exposed to penal sanctions so long as all citizens who would be found culpable of breaking such laws would be exposed to those sanctions. An affront to equality would be the existence of a certain class of people who are 'above the law.' Similarly, treating backsliding states differently from states who are not backsliding is not in conflict with the value of equality as long as the conditionality would apply equally to all member states were they themselves to backslide. 
This insight leads to two concrete principles that must be met in designing of a conditionality mechanism for responding to democracy and rule of law backsliding in the EU. First, the sanctions must be such that all member states could in principle be sanctioned equally - i.e. regardless of their relative wealth or status as net contributors to or beneficiaries of the EU budget and EU structural funds (it is for that reason that I have focused on structural funds and EU investments, rather than on cohesion funds, cf. Šelih et al., 2017). Second, and in contrast to the current process laid out in Article 7, to ensure that any economic conditionality mechanism for democracy and rule of law protection in the EU meets the demand of equality, a stronger place must be given the judicial bodies of the EU, and a correspondingly weaker role to the Council. ${ }^{11}$ Currently, the Council, the Commission and the Parliament have the legal leeway (they 'may' act) to disregard the clear and persistent breach of EU fundamental values. The various EU institutions have unfortunately used this leeway to respond tepidly to quite striking backsliding in some EU states (Pech and Scheppele, 2017). Concretely, it has been noted that the EU's response has been much slower to Hungarian backsliding than Polish backsliding, no doubt in part due to Fidesz' membership of the European People's Party (Kelemen, 2017). Such inequalities already fall foul of the normative drive of the fundamental value of equality (and, arguably, the rule of law), and any economic conditionality regime must ensure that backsliding is responded to by the EU in like cases in a like manner if the mechanism is not itself to prove normatively incoherent. Largely ring-fencing this procedure from the discretion of member state's governments may also have the effect of ensuring that the economic conditionality mechanism is used even when a richer, more powerful member state falls at risk of a serious and persistent breach of Article 2 values, which would be a decision that government ministers in the Council may be wary of.

To summarize, an economic conditionality mechanism to respond to rule of law and democratic backsliding is legitimate, appropriate, sometimes normatively required in light of complicity with autocratization, feasible in light of the competences of the EU and the scope of its activities and, at least potentially, normatively coherent with EU fundamental values. This cannot be said of the current EU rule of law framework under Article 7. The aim of this section has been to set out certain key principles in the design of such a mechanism, but clearly this task remains under-specified. Careful attention to the working out of a conditionality mechanism would be crucial to ensuring that it is not only normatively coherent with the full set of EU fundamental values (we have considered only democratic equality in any detail), but also designed

11 Or creating new judicial or quasi-judicial bodies to oversee such a process, as with the Copenhagen Commission proposed by Müller (2015: 150-151). 
in such a way as to be maximally effective. It is also crucial to ensure that injustices created by such a conditionality mechanism - injustice externalities - are minimized. While this article remains at the level of principle and not of policy design, these matters are the subject of the next and last section.

\section{Alternative funding streams to counteract counterproductive effects and injustice externalities}

In the previous section the focus was on working through the broad lines of the normative case for an economic conditionality mechanism - tying EU funds to democracy and rule of law metrics for instance, or imposing fines for backsliding. Much more work would need to be done (and is being done: e.g. Argyropoulou, 2019; Bachmaier, 2019; Scheppele, 2016; Šelih et al., 2017) on thinking through the contours and details of a workable mechanism of this type in the legal and political constraints and opportunities afforded by EU integration and EU law. In this section however, I deal with two pressing concerns that may call into question the wisdom of going down the route of economic conditionality at all. First, if it is the case, as it seems to be, that economic growth contributes to state's democratic stability, then it may seem counterproductive to impose strong economic conditionality mechanisms on backsliding states. Care should be taken to avoid such counterproductive effects and, at worst, a negative feedback loop that triggers further backsliding. Second, economic conditionality mechanisms against backsliding states may be expected to have a strong impact on many citizens who have no complicity in the backsliding, and may even have actively resisted backsliding in their state with those civil and political freedoms that they continue to enjoy. This seems patently unjust. Perhaps this is a lamentable side-effect of a policy that, all-things-considered, is still the right way for the EU to go, but perhaps certain measures can and ought to be taken to alleviate such injustice externalities.

\section{'Modernization theory' and the risks of a negative feedback loop}

Imposing economic conditionality tools on EU member states already backsliding on democracy and the rule of law could prove counterproductive given the positive relationship between economic growth (which could be slowed by economic conditionality) and democratic stability. The relationship between economic development and democratization or democratic stability is complex and disputed, although analysts agree that there is an important link. In this literature there are broadly two positions: the original 'modernization theory' popularized by Seymour M. Lipset and an alternative position critical of that view that has been called the 'exogenous' view. Lipset held that economic development - growth and wealth - were important causal factors driving democratization, perhaps even prerequisites for the democratization 
of autocratic states (Lipset, 1959; Lipset et al., 1993; Boix and Stokes, 2003). 'Exogenous' accounts, in contrast, argue that the correct link between economic development and democracy is that wealthy, vital democracies are more likely to remain democratic compared to democracies with weak economies (Przeworski and Limongi, 1997: 157).

Clearly, this is not the place to try to adjudicate between these two theories. Nor is it necessary for us to do so, as both ring the same warning bell: imposing thoroughgoing economic conditionality mechanisms as a response to member states backsliding on democracy and the rule of law risks exacerbating democracy concerns in the state in question. Indeed, the worst case scenario of imposing such a conditionality mechanism is that it does not incentivise the relevant government(s) to reform their backsliding activities but rather sparks further processes of de-democratization. In this way, economic conditionality, where it is profound enough to impact a member state's economic vitality, risks generating a negative feedback loop: imposed as a response to concerns over backsliding, the effects may include, indirectly and unintentionally, further backsliding, in turn leading to more stringent conditionality measures, and further backsliding on the back of a still-weaker economy, etc.

While economic conditionality mechanisms may be symbolically powerful responses to rule oflaw and democracybacksliding, if they are counter-productive in the above way they ought not to be part of the EU's toolbox for responding to backsliding. Of course, the precise impact of economic conditionality will depend greatly on the particulars of a given case: for instance, the macroeconomic organization and health of a member state's economy will determine its resilience to conditionality mechanisms. Further, the extent to which a member state's economy is dependent on intra-EU trade will determine how damaging limitations of access to the Single Market are. Similarly, the relative importance of EU structural funds on a state's economy will be reflected in how big the impact would be of tying those funds to performance on rule of law and democracy indicators. Designing an economic conditionality regime that is as effective as possible while constraining these negative externalities will be laborious, but crucial.

\section{Injustice externalities}

A second problem arises due to the unequal distribution of the effects of economic conditionality mechanisms. Were the EU to implement economic conditionality mechanisms on backsliding states, the consequent economic disadvantage, would not be evenly distributed. All things equal, the worse-off are likely to be more strongly affected by disadvantages due to their vulnerability and to diminishing marginal returns on resources. Further, political elites (and the wealthy more generally) in backsliding states will usually have managed 
to secure their own material wellbeing (sometimes indeed on the back of the corruption and cronyism that is the mainstay of backsliding regimes). They will therefore have a relatively larger buffer with which to weather scanter periods. For instance, the $€ 1.67$ billion penalty imposed on Hungary in 2019 for irregularities in the bookkeeping of EU funds will not be paid by those who benefitted most from fudging the numbers, but by ordinary Hungarian tax-payers. ${ }^{12}$

All of this seems remarkably unfair. Why should all individual citizens collectively pay the price for the wrongs of their governments? While some of them will be co-authors of that process of backsliding, and others complicit to it, many others unrelentingly resist and decry their state's backsliding towards illiberalism, populism and authoritarianism. Seen from their perspective, economic conditionality mechanisms seem a very blunt instrument, and any disadvantage they suffer is indeed unjust. I do not wish to get into what distributive justice may or may not require precisely in such cases. But it appears that a wide range of conceptions of non-ideal justice can converge around the view that further harming, say, a civil liberties campaigner in Poland, already maligned and smeared by her government and subjected to increasing limitations on her civil and political freedoms, does not in itself further the cause of justice. Many economic sanctions cannot be appropriately targeted to those responsible for democratic backsliding, and will inevitably harm others who are blameless to these developments. This is an example of the problem of 'injustice externalities.'

One response to the problem of injustice externalities would be to argue that, indeed, some individuals would be pro tanto unjustly disadvantaged by sanctions, but that sanctions should nevertheless be imposed. This type of argument would have to be made on a case-by-case basis, weighing as it does the unjust harms resulting from the conditionality mechanism to the moral urgency to act to resist democratic and rule of law backsliding and express the EU's commitment to the fundamental nature of the values listed in Article 2. But even in cases where it is the case that an economic conditionality mechanism is allthings-considered warranted (or even normatively required) the injustice done to innocent bystanders is not erased. ${ }^{13}$ For this reason, it is important to think

12 Similar criticisms have been made of economic sanctions as tools of foreign policy (Mulder, 2018), although in my view doing nothing in the face of, say, wide-spread human rights violations can also make international trading partners complicit to such wrongdoing.

13 Šelih and her colleagues hint at similar concerns, focused on vulnerable persons in sanctioned states: 'suspending payment of funds [...] may inadvertently harm specific groups of citizens in the target country, particularly those already living in regions significantly poorer than the EU average. This situation would create a moral dilemma for the Commission in deciding how to incentivise the government to improve, without inadvertently punishing the citizens' (Šelih et al., 2017, 12). 
about ways of mitigating the injustice externalities of any sanctions regime, as far as possible, or indeed rejecting specific models of economic conditionality mechanisms where their injustice externalities are too great.

\section{Conclusion: Alternative funding streams}

I have argued that the current Article 7 procedure is in conflict with the values it purports to defend - stripping member states of their right to vote in the Council while continuing to subject them to the authority of Council decisionmaking breaks with the legitimacy demands of democratic equality. An economic conditionality mechanism, potentially comprising cutting off EU structural funds and investments, fining backsliding states, or limiting state's access to the single market can, in contrast, be appropriate, legitimate, scaleable and feasible. It also can be normatively required from the perspective of EU complicity in democratic and rule of law backsliding. However, an economic conditionality mechanism as a democracy support framework resisting democratic and rule of law backsliding may backfire, and can have unjust effects. As such, the 'negative arm' of conditionality should be accompanied by a 'positive arm' of investment in prodemocratic actors.

This conclusion is an initial reflection on the opportunities and potential pitfalls of such a policy. One way to mitigate - though not eliminate - the risks of negative feedback loops and counterproductive effects of an economic conditionality mechanism and at the same time mitigate injustice externalities could be by accompanying economic sanctions (and the withdrawal of benefits) with targeted investment in the backsliding state. The idea is to channel funding from the backsliding state's government to civil society actors, or directly to lower-level state entities, such as regions and municipalities, not controlled by the backsliding state's government. Such a 'positive' arm of an economic mechanism to respond to democracy and rule of law backsliding would vitalise remaining prodemocratic actors in the backsliding state and create new linkages for democracy support, while the 'negative' arm would choke off EU funds and support from the backsliding government and delegitimate the backsliding activities of that government in the eyes of those who take seriously the rule of law and the obligations of their government to uphold shared EU fundamental values. By channelling funds to those who resist the autocratization of their state, such an alternative investment stream would go some way to offset the unjust impact of economic conditionality on those groups. It could also be designed to target particularly vulnerable groups who - regardless of the question of their putative complicity in backsliding - would suffer most from divesting EU funds from their governments. 
At best, such alternative funding streams to prodemocratic actors in a backsliding state would contribute causally to reversing or slowing democratic and rule of law backsliding. This could be by further disincentivizing democracy and rule of law backsliding and incentivizing reform of such activities by backsliding governments, or it could be by strengthening - materially and symbolically - those domestic civil society and political actors resisting backsliding. But even if this ideal outcome of reversing or slowing backsliding is not achieved, such funding would nevertheless send a strong message that the EU is partisan when it comes to democratic equality and the rule of law. In other words, whereas the current Article 7 framework undermines the values of democracy and equality listed in Article 2, funding prodemocratic civil society actors and local and regional governments opposed to democratic and rule of law backsliding by the national government of their state would clearly convey the importance that the EU accords to the Article 2 values.

This partisanship may be seen by some to be an illegitimate interference into the domestic affairs of a member state, or could otherwise be challenged on the grounds that it breaks with the norm of liberal neutrality, stipulating that the EU ought not to take sides in a party-political fashion. Yet, such a critique would misunderstand the intervention, which is only incidentally party-political. As a supranational union of states united in principle around common values, the EU has the authority to act to protect democracy (Müller, 2015). Furthermore, while it is true that backsliding activities can (and, generally, have) been pursued by a particular political party within a member state - think of the PiS party in Poland or Fidesz in Hungary - taking a strong stand against democratic and rule of law backsliding does not break with a principle of EU neutrality vis-a-vis the domestic politics of member states. This is because a prodemocratic orientation and the corresponding resistance to autocratization, while partisan, is neutral to, to use Rawlsian terminology, conceptions of the good and comprehensive religious, philosophical or moral doctrines (see Murray, 2014: 130-132). It is a purely procedural partisan stance favouring certain procedural norms (of equality, democracy, the rule of law, etc.) in the pursuit of political ends. Far from being barred from such partisanship, the EU is compelled to be partisan on such procedural norms in order to guarantee that it is a union sharing the fundamental values listed in Article 2.

Alternative funding streams to prodemocratic actors in member states subjected to economic conditionality for backsliding on democracy and the rule of law would also serve to mitigate some of the aggregate depressive economic effects on the state in question. This may therefore help avoid some of the counterproductive risks of which modernization theory and the 'exogenous' 
account of the relationship between democracy and economic development warn us. By cushioning the macro-economic fallout of the sanctions mechanism, alternative funding streams into a sanctioned state would allay some of the concerns resulting from the link between the health of a state's economy and its democratic health.

The devil is in the details, and the felicity conditions of such EU funding streams would, like the conditionality mechanism itself, need to be carefully and pragmatically planned. Amongst the important normative, legal and policy issues that further research would have to address include who ought to fund prodemocratic civil society actors in backsliding states, which prodemocratic actors should be funded, and how the procedural decision-making apparatus of such an investment mechanism should be designed to maximize the legitimacy of the policy and to minimize cronyism, favouritism and corruption. Despite these important outstanding issues, this article has made a first, principled case for the legitimacy and desirability of such investments in light of, on the one hand, the need for economic conditionality to respond to democratic backsliding in EU member states and, on the other, the injustice externalities and negative feedback loops likely to be consequent to the implementation of such a mechanism. Happily, such a positive investment mechanism would not succumb to the complicity critique made of EU inaction and economic entanglement with the governments of autocratizing member states (discussed in the second subsection of part two, above). It is also, normatively coherent in its support of the EU fundamental values of democracy and equality, unlike the current Article 7 procedure. Empowering prodemocratic actors in a backsliding state may not be enough to stop or reverse the trend of backsliding, but it does at least play in the right direction. ${ }^{14}$

Tom Theuns

Assistant Professor of Political Theory

and European Politics, Leiden University

Associate Researcher at the Centre for European Studies

and Comparative Politics, Sciences Po Paris

email:t.j.h.theuns@fsw.leidenuniv.nl

the global justiceneturork

14 This article has benefited from discussion with and comments from many colleagues. I would particularly like to thank Miriam Ronzoni and Tiziana Torresi and two anonymous reviewers for Global Justice: Theory, Practice, Rhetoric; I also wish to acknowledge Richard Bellamy, Dimitrios Efthymiou, Corrado Fumagalli, Benjamin McKean, Christopher Meckstroth, Eleonora Milazzo, Benjamin Moffitt, Laura Santa Amantini, Kai Spiekermann, Nadia Urbinati, Maria Varaki and Fabio Wolkenstein, the participants of the GJN/TPR/MWP global justice and populism workshop held at the EUI in June 2019. Discussions with Bert van den Brink, Marie-Pierre Granger, Jens van't Klooster, Trudie Knijn, Dorota Lepianka, Barbara Oomen, Orsolya Salát, Andrea Sangiovanni, Frank Vandenbroucke, Philippe Van Parijs and Miklos Zala at the second annual ETHOS conference held at CEU Budapest in January 2019 have helped develop my thoughts on the topic of this article. 


\section{Bibliography}

Abizadeh A (2008) Democratic Theory and Border Coercion: No Right to Unilaterally Control your own Borders. Political Theory 36/1: 37-65.

Argyropoulou V (2019) Enforcing the Rule of Law in the European Union, Quo Vadis EU? Harvard Human Rights Journal. Available at: https://harvardhrj.com/2019/11/enforcing-therule-of-law-in-the-european-union-quo-vadis-eu/ (accessed 1 September 2020).

Bachmaier L (2019). Compliance with the Rule of Law in the EU and the Protection of the Union's Budget. The European Criminal Law Forum 2: 120-126.

Boix C and Stokes S (2003) Endogenous Democratization. World Politics 55/4: 517-549.

European Commission, Secretariat-General (2018) The Proposal for a Regulation of the European Parliament and of the Council on the protection of the Union's budget in case of generalised deficiencies as regards the rule of law in the Member States, COM/2018/324 final - 2018/0136 (COD). Available at: https://eur-lex.europa.eu/legal-content/EN/ TXT/?uri=CELEX\%3A52018PCo324 (accessed 4 September 2020).

Gaedeke D (2016) The Domination of States: Towards an inclusive republican law of peoples. Global Justice: Theory Practice Rhetoric 9/1: 1-27.

Goodin R E (2007) Enfranchising all Affected Interests, and its Alternatives. Philosophy and Public Affairs 35/1: 40-68.

Kelemen R D (2017) Europe's other Democratic Deficit: National Authoritarianism in Europe's Democratic Union. Government and Opposition 52/2: 211-238.

Kelemen R D (2020) The European Union's Authoritarian Equilibrium. Journal of European Public Policy 27/3: 481-499.

Kochenov D (2015) Biting Intergovernmentalism: the case for the reinvention of article 259 TFEU to make it a viable rule of law enforcement tool. Hague Journal on the Rule of Law 7/2: 153-174.

Kochenov D (2017) Busting the Myths Nuclear: A Commentary on Article 7 TEU, EUI Working Paper No. LAW 2017/10. Available at: https://papers.ssrn.com/sol3/papers.cfm?abstract_ id=2965087 (accessed 1 September 2020).

Kochenov D and Pech L (2016) Better Late than Never? On the European Commission's Rule of Law Framework and its First Activation. JCMS: Journal of Common Market Studies 54/5: 1062-1074.

Lepora C and Goodin R E (2013) On Complicity and Compromise. Oxford: Oxford University Press.

Lepora C and Goodin R E (2016) On Complicity and Compromise: A Reply to Peter French and Steven Ratner. Criminal Law and Philosophy 10/3: 591-602.

Lipset S M (1959) Some Social Requisites of Democracy: Economic Development and Political Legitimacy. American Political Science Review 53/1: 69-105. 


\section{CONTAINING POPULISM AT THE COST OF DEMOCRACY? POLITICAL VS. ECONOMIC RESPONSES TO DEMOCRATIC BACKSLIDING IN THE EU}

Lipset S M, Seong K and Torres J (1993) A Comparative Analysis of the Social Requisites of Democracy. International Social Science Journal 45/2: 154-175.

Lopez-Guerra C (2005) Should Expatriates Vote? The Journal of Political Philosophy 13/2: 216-34.

Mulder N (2018) A Leftist Foreign Policy Should Reject Economic Sanctions. The Nation. Available at: https://www.thenation.com/article/archive/sanctions-economy-foreign-policy/ (accessed 1 September 2020).

Müller J-W (2015) Should the EU Protect Democracy and the Rule of Law inside Member States. European Law Journal 21/2: 141-160.

Oliver P and Stefanelli J (2016) Strengthening the Rule of Law in the EU: The Council's Inaction. JCMS: Journal of Common Market Studies 54/5: 1075-1084.

Pech L and Scheppele K L (2017) Illiberalism within: rule of law backsliding in the EU. Cambridge Yearbook of European Legal Studies 19:3-47.

Pech L, Wennerström E, Markowska A, De Keyser L, Leigh V, Agnieszka L, Gómez Rojo A and Spanikova H (2016) An EU mechanism on democracy, the rule of law and fundamental rights: Annex I. Available at: https://www.europarl.europa.eu/RegData/etudes/IDAN/2016/579328/ EPRS_IDA(2016)579328(ANN1)_EN.pdf (accessed 1 September 2020).

Przeworski A and Limongi F (1997) Modernization: Theories and Facts. World Politics 49/2: $155^{-183}$.

Raz J (1992) The Relevance of Coherence. Boston University Law Review 72:273-292.

Scherz A (2013) The Legitimacy of the Demos: Who should be included in the demos and on what grounds? Living Reviews in Democracy 4:1-14.

Scheppele K L (2013) The Rule of Law and the Frankenstate: Why Governance Checklists Do Not Work. Governance 26/4: 559-562.

Scheppele K L (2016) Systemic Infringement Actions. In: Closa C and Kochenov D (eds) Reinforcing Rule of Law Oversight in the European Union? Cambridge: Cambridge University Press.

Song S (2012) The Boundary Problem in Democratic Theory: why the demos should be bounded by the state. International Theory 4/1:39-68.

Šelih J, Bond I and Dolan C (2017) Can EU funds promote the rule of law in Europe? Centre for European Reform policy brief. Available at: https://www.cer.eu/publications/archive/policybrief/2017/can-eu-funds-promote-rule-law-europe (accessed 1 September 2020).

TEU (2012) The Consolidated Version of the Treaty of the European Union. Official Journal of the European Union. Available at: https://eur-lex.europa.eu/resource. html?uri=cellar:2bf14obf-a3f8-4ab2-b506-fd71826e6da6.0023.02/DOC_1\&format=PDF (accessed 3 September 2020).

Theuns T (2017) Promoting Democracy through Economic Conditionality in the ENP: a normative critique. Journal of European Integration 39/3: 297-302.

Theuns T (2019) The Legitimacy of Free Trade Agreements as Tools of EU Democracy Promotion. Cambridge Review of International Affairs 32/1:3-21. 